\title{
HUBUNGAN AKTIVITAS FISIK DAN POLA KONSUMSI TERHADAP INSIDEN OBESITAS SENTRAL
}

\author{
Ririn Pakaya ${ }^{1}$ *, Franning Deisi Badu ${ }^{2}$, Lun Irmawati Maliki ${ }^{3}$ \\ ${ }^{123}$ Universitas Gorontalo, Gorontalo, Indonesia, 96213 \\ *Coressponding Author: ririn.pakaya@mail.ugm.ac.id
}

\section{Keterangan}

Rekam Jejak:

Received, Oktober 2020

Revised, November 2020

Accepted, Desember 2020

Kata Kunci:

Aktivitas Fisik, Pola Konsumsi, Obesitas Sentral
Obesitas menjadi salah satu masalah kesehatan utama di dunia dan di negara berkembang berada pada urutan ke lima. WHO menyatakan bahwa obesitas telah menjadi epidemi global sehingga obesitas perlu segera ditangani karena sudah menjadi masalah Kesehatan (Rahmandita \& Adriani, 2017). Obesitas sentral yaitu obesitas yang menyerupai apel, yaitu lemak disimpan pada bagian pinggang dan ronga perut. Penumpukan lemak ini diakibatkan oleh jumlah lemak berlebih pada jaringan lemak subkutan dan lemak viseral perut. Data yang diperoleh dari Dinas Perhubungan Provinsi Gorontalo tahun 2019 menunjukan bahwa jumlah Supir Angkutan di Provinsi Gorontalo berjumlah 828 pengemudi yang berasal dari 6 Kabupaten yang ada di Provinsi Gorontalo. Penelitian ini bertujuan untuk melihat hubungan ativitas fisik dan pola konsumi terhadap kajadian obesitas sentral pada supir angkot di Kota Gorontalo. Jenis penelitian yang digunakan biasa disebut penelitian observasional analitik atau desain penelitian Cross Sectional. Lokasi penelitian ini bertempat di Terminal Dungingi Jalan Beringin Kelurahan Huangobotu Kecamatan Dungingi. Penelitian ini dilaksanakan pada bulan Juni-Juli tahun 2020. Sampel dalam penelitian ini merupakan sebagian supir angkot yang berada di Kota Gorontalo dengan jumlah 201 sampel. Ada hubungan Aktivitas fisik dengan kejadian obesitas sentral pada supir angkot dikota Gorontalo dengan nilai $\mathrm{p}=0,048<0,05$. Tidak ada hubungan konsumsi karbohidrat dengan insiden obesitas sentral pada supir angkot di Kota Gorontalo dengan nilai Fishers Exact $=0,774>0,05$. Ada hubungan konsumsi lemak dengan insiden obesitas sentral pada supir angkot di Kota Gorontalo dengan nilai $p=0,00<0,05$. Tidak ada hubungan konsumsi karbohidrat dengan insiden obesitas sentral pada supir angkot di Kota Gorontalo dengan Nilai $\mathrm{p}=1>0,05$.

Copyright (C) 2020

Jurnal Olahraga \& Kesehatan Indonesia 


\section{PENDAHULUAN}

Obesitas adalah masalah kesehatan masyarakat yang signifikan yang mempengaruhi lebih dari setengah miliar orang di seluruh dunia. Kenaikan obesitas tidak hanya terbatas di negara maju, tetapi juga di negara berkembang (Bhurosy \& Jeewon, 2014). Obesitas menjadi salah satu masalah kesehatan utama di dunia dan di negara berkembang berada pada urutan ke lima. WHO menyatakan bahwa obesitas telah menjadi epidemi global sehingga obesitas perlu segera ditangani karena sudah menjadi masalah Kesehatan (Rahmandita \& Adriani, 2017). Obesitas sentral yaitu obesitas yang menyerupai apel, yaitu lemak disimpan pada bagian pinggang dan ronga perut. Penumpukan lemak ini diakibatkan oleh jumlah lemak berlebih pada jaringan lemak subkutan dan lemak viseral perut. penumpukan lemak pada jaringan lemak viseral merupakan bentuk dari tidak berfungsinya jaringan lemak subkutan dalam menghadapi kelebihan energi akibat konsumsi lemak berlebih (Puspitasari, 2018). Melakukan aktivitas fisik yang lama sangat membantu dalam mencegah terjadinya kenaikan berat badan. Penurunan berat badan dengan aktivitas fisik dapat mengurangi risiko kardiovaskuler dan diabetes dibandingkan penurunan berat badan tanpa aktivitas fisik (Harikedua \& Tando, 2012).

Aktivitas fisik merupakan komponen penting dari intervensi gaya hidup untuk menurunkan dan mempertahankan berat badan. Meskipun efek aktivitas fisik pada penurunan berat badan mungkin tampak sederhana, namun ada hubungan respons-dosis antara aktivitas fisik dan penurunan berat badan. Aktivitas fisik juga merupakan perilaku yang sangat penting untuk mendorong penurunan berat badan jangka panjang dan mencegah berat badan Kembali (Jakicic \& Davis, 2011). Obesitas sentral dapat terjadi karena adanya perubahan gaya-hidup, seperti tingginya konsumsi minuman beralkohol, kebiasaan merokok, tingginya konsumsi makanan berlemak, rendahnya konsumsi sayuran dan buah, dan rendahnya aktivitas fisik. Selain itu, peningkatan umur, perbedaan jenis kelamin, dan status sosial ekonomi diduga juga berhubungan dengan kejadian obesitas sentral. Peningkatan prevalensi obesitas sentral berdampak pada munculnya berbagai penyakit degeneratif. Obesitas sentral berhubungan dengan peningkatan sindrom metabolik, aterosklerosis, penyakit kardiovaskuler, diabetes tipe 2, batu empedu, gangguan fungsi pulmonal, hipertensi dan dyslipidemia (Yusuf, 2014). Pengemudi angkot antar kota merupakan pekerjaan dengan risiko tinggi terkena penyakit kardiometabolik, hal ini disebabkan pola hidup dan pola kerja yang sanga tidak baik semacam konsumsi makanan berlemak berlebih, durasi menyetir yang lama dan pola tidur yang tidak teratur. Waktu kerja yang panjang sebagai pengemudi angkot dapat menyebabkan perilaku yang menetap, yaitu kurangnya Aktivitas fisik dan pola makan yang buruk, yang berkontribusi pada risiko terjadinya obesitas dan obesitas sentral. Data yang diperoleh dari Dinas Perhubungan Provinsi Gorontalo tahun 2019 menunjukan bahwa jumlah Supir Angkutan di Provinsi Gorontalo berjumlah 828 pengemudi yang berasal dari 6 Kabupaten yang ada di Provinsi Gorontalo (Dinas Perhubungan, 2019). Penelitian ini bertujuan untuk melihat hubungan ativitas fisik dan pola konsumi terhadap kajadian obesitas sentral pada supir angkot di Kota Gorontalo. Berdasarkan permasalahan diatas, maka peneliti terdorong melakukan penelitian mengenai faktor yang berhubungan dengan kejadian obeistas sentral pada supir angkot di Kota Gorontalo.

\section{METODE}

Jenis penelitian yang digunakan biasa disebut penelitian observasional analitik atau desain penelitian Cross Sectional. Lokasi penelitian ini bertempat di Terminal Dungingi Jalan Beringin Kelurahan Huangobotu Kecamatan Dungingi. Penelitian ini dilaksanakan pada bulan Juni-Juli tahun 2020. Populasi dalam penelitian ini adalah seluruh supir yang ada di Kota Gorontalo yang berjumlah 828 pengemudi. Sampel adalah bagian yang diambil dari keseluruhan obyek yang diteliti dan dianggap mewakili seluruh populasi. Sampel dalam penelitian ini merupakan sebagian supir angkot yang berada di Kota Gorontalo dengan jumlah 201 sampel. 
Penentuan besar sampel di lakukan dengan menggunakan rumus Lemeshow (Lemeshow et al., 1990):

$$
n=\frac{\mathrm{N} \cdot Z^{2} \cdot \mathrm{P} \cdot \mathrm{q}}{\mathrm{d}^{2}(\mathrm{~N}-1)+\mathrm{Z}^{2} \cdot \mathrm{P} \cdot \mathrm{q}}
$$

Variabel dalam penelitian ini terdiri dari Variabel Independent: Aktivitas Fisik dan Pola Konsumsi (Karbohidrat, Lemak dan Protein). Sedangkan Variabel Dependent adalah Obesitas Sentral. Analisis data menggunakan SPSS (Statistical Package and Social Siences) untuk analisis univariat dan analisis bivariat. Analisis bivariat dilakukan untuk melihat hubungan antara variabel Independent dan varibel dependent. Teknik analisis data yang digunakan dalam peneltian ini digunakan uji statistik Chi-Square dengan uji $x^{2}$ (Chi-Square) yang bertujuan menguraikan hipotesis hubungan variabel yang independent dan veriabel dependent.

\section{HASIL \& PEMBAHASAN}

Analisis Univariat

Distribusi Obesitas Sentral

Pada tabel 1, distribusi responden menurut obesitas sentral pada supir angkot di Kota Gorontalo menunjukan bahwa dari 201 responden yang diuji, jumlah sampel tertinggi adalah responden dengan kategori normal yaitu sebanyak 124 responden $(61,7 \%)$ dan responden dengan kategori obesitas sentral sebanyak 77 (38,3\%).

Tabel 1. Distribusi Responden menurut Obesitas Sentral

\begin{tabular}{ccc}
\hline \multicolumn{2}{c}{ Tabel 1. Distribusi Responden menurut } & Obesitas Sentral \\
Kategori & Frekuensi & Persentase \\
Obesitas & 77 & 38,3 \\
Normal & 124 & 61,7 \\
Total & 201 & 100,0 \\
\hline
\end{tabular}

Obesitas merupakan suatu kondisi ketidakseimbangan antara tinggi badan dan berat badan akibat jumlah jaringan lemak tubuh yang berlebihan, umumnya ditimbun dalam jaringan subkutan, sekitar organ tubuh dan kadang terjadi infiltrasi ke dalam organ tubuh. Obesitas terdiri dari 2 macam yaitu obesitas umum dan obesitas sentral/abdominal. Obesitas umum dapat diketahui melalui indikator IMT 30,0 - 34,9 (Listiyana et al., 2013).

Distribusi Aktivitas Fisik

Pada tabel 2 menunjukkan bahwa dari 201 responden yang diteliti, responden dengan kategori aktif yaitu berjumlah 157 responden $(78,1 \%)$ dan responden dengan kategori kurang aktif berjumlah 44 responden $(21,9 \%)$.

Tabel 2. Distribusi Responden menurut Aktivitas Fisik

\begin{tabular}{ccc}
\hline Aktivitas Fisik & $\mathrm{N}$ & $\%$ \\
Aktif & 157 & 78,1 \\
Kurang Aktif & 44 & 21,9 \\
Total & $\underline{201}$ & $\underline{100,0}$ \\
\hline
\end{tabular}

Salah satu penggunaan energi (energy expediture) terbesar adalah dengan melakukan Aktivitas fisik. Jaringan lemak terbentuk karena kurangnya pemakaian energi sehingga menyebakan tidak seimbangnya antara pemasukan dan pemakain energi serta hal tersebut menyebabkan timbulnya obesitas pada seseorang (Octari \& Liputo, 2014). Dalam penelitian ini bahwa Aktivitas fisik dinilai dengan menghitung waktu yang digunakan oleh responden untuk melakukan Aktivitas fisik tanpa menilai intensitasnya. Hasilnya akan digolongkan menjadi "aktif" dan "kurang aktif". 
Distribusi Pola Makan

Konsumsi Karbohidrat

Pada Tabel 3 menunjukkan data dari 201 responden, yang mengkonsumsi karbohidrat dengan kategori tidak berisiko yaitu sebanyak 191 responden (95\%) dan yang berisiko sebanyak 10 responden $(5 \%)$.

Konsumsi Lemak

Pada tabel 3 menunjukkan dari 201 responden, yang mengkonsumsi konsumsi lemak dengan kategori berisiko yaitu sebanyak 107 responden $(53,2 \%)$ dan yang tidak berisiko sebanyak 94 responden $(46,8 \%)$.

Konsumsi Protein

Untuk kategori konsumsi protein dari 201 responden yang diteliti, yang mengkonsumsi protein dengan kategori berisiko yaitu sebanyak 102 responden $(50,7 \%)$ dan yang tidak berisiko sebanyak 99 responden $(49,3 \%)$.

Tabel 3. Distribusi Responden menurut Pola Makan

\begin{tabular}{cccccc}
\hline Aktivitas Fisik & Beresiko & $\%$ & Tidak Beresiko & $\%$ & Jumlah \\
Konsumsi Karbohidrat & 10 & 5 & 191 & 95 & 201 \\
Konsumsi Lemak & 107 & 53,2 & 94 & 46,8 & 201 \\
Konsumsi Protein & 102 & 50,7 & 99 & 49,3 & 201 \\
\hline
\end{tabular}

Analisis Bivariat

Hubungan Aktivitas Fisik dengan Kejadian Obesitas Sentral

Berdasarkan tabel 4 melalui uji chi-square menunjukan bahwa dari 201 (100,0\%) responden dengan kategori Aktivitas fisik aktif terdapat 54 responden $(26,9 \%)$ mengalami obesitas sentral dan dari 44 responden dengan Aktivitas fisik kurang aktif terdapat 23 responden $(11,4 \%)$ tergolong obesitas sentral. Dari hasil uji statistik maka didapatkan hasil nilai $x^{2}$ hitung adalah 3,922> $>x^{2}$ tabel 3,841 maka disimpulkan bahwa Ho ditolak dan Ha diterima atau ada hubungan antara Aktivitas fisik dengan kejadian obesitas sentral pada supir angkot di Kota Gorontalo tahun 2020. Dengan nilai $p$ value diperoleh $0,048<\alpha 0,05$ hal ini menunjukan hubungan signifikan.

Tabel 4. Hubungan Aktivitas Fisik dengan Kejadian Obesitas Sentral

\begin{tabular}{cccccccc}
\hline & \multicolumn{2}{c}{ Obesitas Sentral } & \multicolumn{2}{c}{ Normal } & \multicolumn{2}{c}{$x^{2}$} & $\begin{array}{c}\text { Hitung } \\
\text { P-value }\end{array}$ \\
Aktivitas Fisik & $\mathrm{n}$ & $\%$ & $\mathrm{~N}$ & $\%$ & & & \\
& 54 & 70,1 & 103 & 83,1 & 157 & 78,1 & 3,922 \\
Aktif & 23 & 29,9 & 21 & 16,9 & 44 & 21,9 & 0,048 \\
Kurang Aktif & 77 & 100 & 124 & 100 & 201 & 100,0 & 0.04 \\
Jumlah & &
\end{tabular}

Hubungan Pola Makan (Karbohidrat) dengan Kejadian Obesitas Sentral

Berdasarkan tabel 5 hasil uji chi-square menunjukan bahwa dari $201(100,0 \%)$ responden terdapat 3 responden berisiko $(1,5 \%)$ mengalami obesitas sentral dan dari 191 responden tidak berisiko terdapat 74 responden $(36,8 \%)$ mengalami obesitas sentral. Berdasarkan hasil analisa diperoleh nilai uji Fishers Exact karena uji Chi-Square tidak memenuhi syarat. Maka nilai perbandingan Fishers Exact diperoleh 0,774 $>\alpha$ 0,05 maka H0 di terima dan Ha di tolak atau ttidak ada hubungan konsumsi karbohidrat dengan kejadian obesitas sentral pada supir angkot di Kota Gorontalo. 
Tabel 5. Hubungan Konsumsi Karbohidrat dengan Kejadian Obesitas Sentral

\begin{tabular}{cccccccc}
\hline \multirow{2}{*}{ Konsumsi Karbohidrat } & \multicolumn{2}{c}{ Obesitas } & \multicolumn{2}{c}{ Normal } & \multirow{2}{*}{ F } & $\%$ & \multirow{2}{*}{ Fishers } \\
& $\mathrm{n}$ & $\%$ & $\mathrm{~N}$ & $\%$ & & & \\
Beresiko & 3 & 3,9 & 7 & 5,6 & 10 & 5,0 & \\
Tidak Beresiko & 74 & 96,1 & 117 & 94,4 & 191 & 95,0 & 0,744 \\
Jumlah & 77 & 100 & 124 & 100 & 201 & 100,0 & \\
\hline
\end{tabular}

Penelitian ini tidak sejalan dengan penelitian yang dilakukan oleh (Dewi \& Mahmudiono, 2013) dimana dalam penelitian tersebut menunjukkan terdapat hubungan antara frekuensi konsumsi nasi dengan status gizi $(p=0,015)$. Hal ini karena karbohidrat merupakan salah satu penyumbang energi terbesar dalam tubuh dan nasi merupakan sumber karbohidrat yang paling banyak dikonsumsi oleh sebagian besar masyarakat di Indonesia. Namun penelitian ini sejalan dengan penelitian yang dilakukan oleh (Sofa, 2018) yakni dalam penelitian ini ditemukan bahwa asupan zat gizi (energi, protein, lemak, karbohidrat, dan serat) tidak memiliki hubungan yang signifkan dengan kejadian obesitas maupun obesitas sentral ( $p$-value $>0,05$ ).

Hubungan Pola Makan (Lemak) dengan Kejadian Obesitas Sentral Pada Supir Angkot

Pada tabel 6 dengan uji chi-square menunjukan bahwa dari $201(100,0 \%)$ responden terdapat 63 responden dengan konsumsi lemak berlebih $(81,8 \%)$ mengalami obesitas sentral dan 14 responden $(18,2 \%)$ dengan konsumsi lemak tidak berlebih mengalami obesitas sentral. Hasil uji statistik maka diperoleh hasil nilai $x^{2}$ hitung adalah 39,124> $x^{2}$ tabel 3,841 maka Ho ditolak dan Ha diterima atau ada hubungan antara yang signifikan konsumsi lemak dengan insiden obesitas sentral pada supir angkot di Kota Gorontalo. Dengan nilai $p$ value diperoleh $0,000>\alpha 0,05$ hal ini menunjukan bahwa hubungan signifikan.

Tabel 6. Hubungan Konsumsi Lemak dengan Kejadian Obesitas Sentral

\begin{tabular}{cccccccc}
\hline & \multicolumn{2}{c}{ Obesitas Sentral } & \multicolumn{2}{c}{ Normal } & \multicolumn{2}{c}{$x^{2}$} \\
Konsumsi Lemak & $\mathrm{n}$ & $\%$ & $\mathrm{~N}$ & $\%$ & $\mathrm{n}$ & $\%$ & $\begin{array}{c}\text { Hitung } \\
\text { P-value }\end{array}$ \\
Beresiko & 63 & 81,8 & 44 & 35,5 & 127 & 63,2 & 39,124 \\
Tidak Beresiko & 14 & 18,2 & 80 & 64,5 & 74 & 36,8 & 3,000 \\
Jumlah & 77 & 100 & 124 & 100 & 201 & 100,0 & 0,000 \\
\hline
\end{tabular}

Obesitas sentral didefinisikan sebagai kelebihan lemak perut atau lemak pusat. Faktor langsung yang menyebabkan obesitas sentral yaitu makanan dan minuman manis, makanan tinggi lemak, serta konsumsi sayur dan buah yang rendah. Pengonsumsian makanan jenis ini dapat membawah menuju penyakit degeneratif. Makanan manis dan makanan berlemak meningkatkan berat tubuhdan lingkar perut. Hubungan ini diduga karena kombinasi antara makanan berlemak dengan makanan manis. Makanan manis seringkali kaya lemak. Konsumsi makanan manis dan berlemak yang berlebihan juga dapat memberikan kontribusi energi yang dapat disimpan sebagai lemak dalam tubuh sehingga meningkatkan risiko obesitas sentral (Tumaluntung \& Ticoalu, 2015).

Hubungan Pola Makan (Protein) dengan Kejadian Obesitas Sentral Pada Supir Angkot

Pada tabel 7 melalui uji chi-square menunjukan bahwa dari $201(100,0 \%)$ responden terdapat 39 responden dengan konsumsi protein berlebih (50,6\%) mengalami obesitas sentral dan 38 responden $(49,8 \%)$ dengan konsumsi protein tidak berlebih tergolong obesitas sentral. Hasil uji statistik maka diperoleh hasil nilai $x^{2}$ hitung adalah $0,000<x^{2}$ tabel 3,841 maka Ho diterima dan $\mathrm{Ha}$ ditolak atau tidak ada hubungan antara konsumsi protein dengan kejadian obesitas sentral pada supir angkot di Kota Gorontalo. Dengan nilai $p$ value diperoleh $1>\alpha 0,05$ hal ini menunjukan bahwa hubungan tidak signifikan. 
Tabel 7. Hubungan Konsumsi Protein dengan Kejadian Obesitas Sentral

\begin{tabular}{cccccccc}
\hline & \multicolumn{2}{c}{ Obesitas } & \multicolumn{2}{c}{ Normal } & $\mathrm{n}$ & $\%$ & $\begin{array}{c}x^{2} \\
\text { Hitung } \\
\text { Konsumsi Protein }\end{array}$ \\
& $\mathrm{n}$ & Sentral & $\mathrm{N}$ & $\%$ & & & P-value \\
Beresiko & 39 & 50,6 & 63 & 50,8 & 102 & 50,7 & 1,000 \\
Tidak Beresiko & 38 & 49,8 & 61 & 49,2 & 99 & 49,3 & 0,000 \\
Jumlah & 77 & 100 & 124 & 100 & 201 & 100,0 & 0,000 \\
\hline
\end{tabular}

Penelitian ini tidak sejalan dengan penelitian yang dilakukan oleh (Bertalina \& Muliani, 2016) menunjukkan bahwa hasil uji statistik diperoleh nilai $p$ value sebesar 0,001 (lebih kecil dari nilai alpha $=0,050$ ) yang berarti Ho ditolak sehingga dapat disimpulkan ada hubungan yang signifikan antara asupan protein hewani dengan tekanan darah pasien hipertensi di Puskesmas Rajabasa Indah Kota Bandar Lampung Tahun 2015.

\section{SIMPULAN}

Ada hubungan aktivitas fisik dengan kejadian obesitas sentral pada supir angkot dikota Gorontalo dengan nilai $\mathrm{p}=0,048<0,05$. Tidak ada hubungan konsumsi karbohidrat dengan insiden obesitas sentral pada supir angkot di Kota Gorontalo dengan nilai Fishers Exact $=0,774$ $>0,05$. Ada hubungan konsumsi lemak dengan insiden obesitas sentral pada supir angkot di Kota Gorontalo dengan nilai $p=0,00<0,05$. Tidak ada hubungan konsumsi karbohidrat dengan insiden obesitas sentral pada supir angkot di Kota Gorontalo dengan Nilai $\mathrm{p}=1>0,05$.

\section{DAFTAR PUSTAKA}

Bertalina, B., \& Muliani, M. (2016). Hubungan Pola Makan, Asupan Makanan dan Obesitas Sentral dengan Hipertensi di Puskesmas Rajabasa Indah Bandar Lampung. Jurnal Kesehatan, 7(1), 34. https://doi.org/10.26630/jk.v7i1.116

Bhurosy, T., \& Jeewon, R. (2014). Overweight and obesity epidemic in developing countries: A problem with diet, physical activity, or socioeconomic status? Scientific World Journal, 2014. https://doi.org/10.1155/2014/964236

Dewi, A., \& Mahmudiono, T. (2013). Hubungan Pola Makan, Aktivitas Fisik, Sikap, dan Pengetahuan Tentang Obesitas dengan Status Gizi Pegawai Negeri Sipil di Kantor Dinas Kesehatan Provinsi Jawa Timur. Jurnal Media Gizi Indonesia, 9(1), 42-48.

Dinas Perhubungan. (2019). Profil Dinas Perhubungan Provinsi Gorontalo.

Harikedua, V. T., \& Tando, N. M. (2012). Aktivitas Fisik dan Pola Makan dengan Obesitas Sentral pada Tokoh Agama di kota Manado. Gizido, 4(1), 289-298.

Jakicic, J. M., \& Davis, K. K. (2011). Obesity and physical activity. Psychiatric Clinics of North America, 34(4), 829-840. https://doi.org/10.1016/j.psc.2011.08.009

Lemeshow, S., Hosmer, D. W., Klar, J., \& World Health Organization. (1990). Adequacy of Sample Size in Health Studies. In World Health Organization 47(1). https://doi.org/10.2307/2532527

Listiyana, A. D., Mardiana, \& Prameswari, G. N. (2013). Obesitas Sentral Dan Kadar Kolesterol Darah Total. KESMAS - Jurnal Kesehatan Masyarakat, 9(1), 37-43. https://doi.org/10.15294/kemas.v9i1.2828

Octari, C., \& Liputo, N. I. (2014). ArtikelPenelitian Hubungan Status Sosial Ekonomi dan Gaya Hidup dengan Kejadian Obesitas pada Siswa SD Negeri 08 Alang Lawas Padang. $3(2), 131-135$.

Puspitasari, N. (2018). Kejadian Obesitas Sentral pada Usia Dewasa. HIGEIA (Journal of Public Health Research and Development), 2(2), 249-259. https://doi.org/10.15294/higeia.v2i2.21112 
Rahmandita, A. P., \& Adriani, M. (2017). Perbedaan Tingkat Konsumsi dan Aktivitas Fisik pada Wanita (20-54 Tahun) Obesitas Sentral dan Non Sentral. Amerta Nutrition, 1(4), 266. https://doi.org/10.20473/amnt.v1i4.7124

Sofa, I. M. (2018). Kejadian Obesitas, Obesitas Sentral, dan Kelebihan Lemak Viseral pada Lansia Wanita. Amerta Nutrition, 2(3), 228. https://doi.org/10.20473/amnt.v2i3.2018.228-236

Tumaluntung, D. I. D., \& Ticoalu, M. A. C. (2015). Angka Kejadian Obesitas Sentral Pada Wanita. Jurnal E-Biomedik (EBm), 3, 1-4.

Yusuf, H. S. H. M. (2014). Faktor yang Berhubungan dengan Kejadian Obesitas Sentral di Poliklinik Pabrik Gula Camming PTP Nusantara X (Persero) Kab. Bone. Jurnal Ilmiah Kesehatan Diadnosis, 5, 594-600. 